\title{
INVESTIGASI PENDEK ATAS KESEJARAHAN TEORI HUKUM, SELAKU DISIPLIN YANG MENGEMBAN MISI TEORETIKAL BIDANG HUKUM
}

\author{
Rahadjeng Endah KS.
}

\begin{abstract}
Abstrak
The work of Hans Kelsen which is known as "The Theory of Pure Science of Law" different from that of the Theory of Jurisprudence or in Dutch as "Alegemeine Rechtleer". He desires to create a pure science of law, stripped from all irrelevant, and to separate jurisprudence from the social sciences. Kelsen refuses to define law as a command, for that introduces subjective and political considerations and he wishes his science to be truly objective. He wishes to separate the Realm of Jurisprudence from that of Natural Science, the latter deals with couses and effects. Law and the State one really the same thing envisaged from different aspects. A legal order becomes a State when it has developed organs for the creation, declaration, and enforcement of law. When we look at the abstract rules we think of the legal order, when we examine the institutions by which law is put into effect we think of the State. But it is merely looking at the same thing from two angles.
\end{abstract}

Kata kunci: teori hukum murni, ilmu hukum, ajaran hukum

\section{Pendahuluan}

Sebagaimana halnya "Ilmu Hukum", ilmu tertua yang sentra pengembanannya dijalankan "organ-organ motorik" dari hukum itu sendiri, yang puas diri dengan kemasyhurannya selaku "ajaran ilmu dari hukum positif' (ilmu tentang hukum positif), Teori Hukum yang dijalankan teoretisi hukumpun ketika menyatakan diri sebagai suatu disiplin (ilmiah positif), meski tak bisa lain selain membiarkan dirinya terposok di lubang-lubang anormatif, tentu akan bersiap diri untuk pula didaulat sebagai "teori ilmu tentang hukum positif". Sebab dengan teori-teori yang dimaterialkannya itu, perjalanan ruang pengelahan praktikal hukum, terutama dalam hendak menginterpretasi unit-unit kaidah hukum yang hasilnya harus dikonfrontasi pada fakta-fakta yang di justifikasi (proses penalaran dalam Ilmu Hukum),

${ }^{1}$ Antara lain para pengemban profesi yang dilimpahkan wewenang untuk membuat keputusan hukum, seperti: hakim, pengacara, jaksa, notaris, polisi dan seterusnya. 
dapat digelar secara ilmiah, terang, dan jernih. Anda bisa mempresisi ini, pada bagaimana ilmu ini mengerjakan pekerjaan ilmiah yang oleh Kelsen disebut "analisa positif" (analisa ilmiah). ${ }^{2}$ Dimana sesungguhnya, untuk menolong Ilmu Hukum memecahkan problem-problem hukum di tataran praktikal, ia telah sekalian membuka diri bagi masuknya "teori-teori" yang ditemukan berbagai disiplin ilmu" yang mungkin" (yang relevan), baik yang dengan sengaja memusatkan diri pada hukum (semisal Sosiologi Hukum, Analisa Ekonomi Terhadap Peristiwa Hukum dan seterusnya), maupun yang sama sekali tidak (semisal Kedokteran Forensik, Balistik dan seterusnya).

Dengan demikian, dalam keberdiriannya selaku medan pengembanan teoretikal bidang hukum, ia telah sekaligus mengeksposisi diri sebagai disiplin interdisipliner (disiplin yang menjadi kutub bertemunya keseluruhan bidang ilmu) yang secara kritikal berupaya mengurai berbagai aspek gejala hukum secara tersendiri dan keseluruhannya, baik dalam konsepsi teoretikalnya maupun dalam pengolahan praktikalnya, dengan tujuan memperoleh pemahaman yang lebih jernih atas gejala-gejala hukum yang diperhadapkan padanya. Karena ciri pragmatikalitas sedemikian, wilayah kiprahnya boleh dibilang akan sangat terikat pada dimensi praktikal hukum, suatu keterikatan yang di dalamnya diperlihatkan kompleksitas dari tradisi berpikir dan bermetode aspek-aspek keilmuan tertentu. Karena keterikatan ini, tentu saja dalam rute-rute yang mau dilalui, iapun sama sekali harus menjauhkan diri dari spekulasi-spekulasi berbau metafisikal, sebagaimana yang sebelumnya dipertontonkan para filsuf dalam Filsafat Hukum.

Demikianlah, di sini kita tidak hendak membicarakan derajat pragmatikalitas dari ilmu ini, sebab pemunculan naskah ini sendiri, dilatari oleh rasa keingintahuan penulis untuk menguak lebih jauh tabir yang menguak lebih jauh tabir yang menyelubungi tiga tahap perkembangan dari ilmu ini (Teori Hukum), yang ke tengah-tengah kita, telah hadir sebagai satusatunya ilmu a-normatif yang telah sampai pada usaha memerhatikan hukum dengan menunggang optic berskala interperspektif. Tahap-tahap itu antara lain: fase pra-Teori Hukum yang muncul pada akhir abad ke-18, fase Teori Hukum Murninya Hans Kelsen, serta fase Teori Hukum sebagai disiplin ilmiah mandiri.

2 Perkataan positif di atas dimaksudkan sebagai cara berpikir positif yang dikembangkan dalam Positivisme Empirik, sebagaimana telah dipopulerkan Comte. Untuk lebih memahami aliran ini, anda bisa menelurusrinya pada essay yang ditulis Moritz Schlick, "Positivism and Realism" dalam: "The Philosophy of Science", edited by: Richard Boyd, Philip Gasper, and J.D. Trout, (London: The MIT Press, 1997), hal. 37-55. 


\section{Allgemeine Rechtslehre, Sebuah Fase Pra-Teori Hukum}

Pada fase kemunculannya yang pertama, beberapa penulis mengemukakan kemungkinan besar medan-medan penelitian Teori Hukum terampil di Rusia. Soal kapan persisnya, kami tidak begitu yakin, tapi sebuah sumber mengonfirmasi bahwa peristiwa kemunculan ini setidaknya terjadi sekitar peralihan dari abad ke 19 ke abad 20. Meski pada gilirannya seolah ia seperti lenyap ditelan kabut yang menyelimuti tebing-tebing kesejarahan, sebab publikasi yang atasnya digelar dianggap tidak begitu mengalami kecukupan berartian, tapi di beberapa kepustakaan di Polandia justru disebutkan bahwa ia tidak begitu saja lenyap. Teori Hukum di Rusia itu bahkan sedikit banyak memberikan pengaruh bagi berkembangnya pemikiran mengenai pokok-pokok telaah yang masuk ke dalam 'domein' Teori Hukum, sebagaimana yang hingga hari ini didiskursuskan oleh banyak penulis di Eropa Daratan. Menurut Meuwissen sebutan yang pertama kali diberlakukan untuk perkataan Teori Hukum adalah "Ajaran Hukum" (Rechtsleer). Ajaran Hukum yang dimaksudkan disini, adalam kesibukannya selalu berurusan dengan persoalan analisasi dan eksplanasi pelbagai konsep-konsep dan pengertian yang digunakan di bidang hukum. Kita tentu sering mendengar orang menyebut istilah: asas hukum, hukum subjektif, hukum obyektif, hubungan hukum, judicial, peradilan hak, kewajiban, kontrak, kesepakatan, hukuman denda, itikad-baik, dan seterusnya. Kesemuanya itu adalah pusat perhatian dari Ajaran Hukum. Namun tidak jelas apakah perkataan Ajaran Hukum itu ada pertaliannya dengan istilah Allgemeine Rechtslehre (yang menjadi sub judul di atas). Bila saja ada pertaliannya, mungkin yang dimaksudkan Muewissen dengan Ajaran Hukum di situ sama halnya dengan apa yang di Jerman disebut dengan Allgemeine Rechtslehre itu (Ajaran Hukum Umum) atau mungkin juga sebagai ajaran yang muncul mendahului sebelum kemunculan Allgeine Rechtslehre.

Sehubungan dengan itu, bahwa Teori Hukum di Rusia ini sendiri, justru tampil sebagai upaya eksploratif atas gagasan Allgemeine Rechtslehre (Ajaran Hukum Umum, Algemeene Rechtsleer, general jurisprudence theorie generale dudroit) yang sebelumnya digiatkan di tanah Eropa Daratan itu sendiri. Ajaran ini adalah suatu disiplin ilmiah-positif yang ke permukaan muncuk sekitar 1870-an, dan terkait nama beberapa eksponennya yang sangat masyhur di Eropa, yang terdiri dari seorang Inggris, John Austin (1790-1859), beberapa orang Jerman seperti: Adolf Merkel (1836-1896), Karl Bergbohm (1849-1927), Ernst Rudolf Bierling (1841-1919) dan Rudolf Stamler (1856-1936), Adolf Reinach (1883-1917), serta seorang Ceko, Felix Comlo (1873-1920). Mereka dengan Algemeene Rechtsleer-nya itu, ingin 
melahirkan sebuah disiplin ilmiah-positif yang baru, yang lebih teoretikal ketimbang Ilmu Hukum, namun lebih aktual ketimbang Filsafat Hukum.

Sisi keaktualisasian dan keteoritikalitasan itu misalnya Nampak pada bagaimana Austin dengan The Command Theory of Law-nya menyinggungnyinggung sebuah Filsafat mengenai hukum positif, lalu Merkel yang berusaha menelusuri generalisasi (kesamaan) pada sisi-sisi yang hakiki (hakikat) dari hukum dengan mengemukakan "bagian-bagian umum Ilmu Hukum", Reinach yang dalam kesibukannya berupaya membangun suatu ontology dari hukum yang bersifat platonic, atau Stamler yang sebagaimana juga Merkel menggagas sebua ide tentang "Ajaran Hukum Murni" pada fase pertama. Secara garis besar, dengan ajaran ini, pada dirinya orang-orang ini berhendak menyibukkan diri dengan pertanyaan-pertanyaan yang seperti para filsuf menyibukkan diri, tapi dari sudut atau perspektif yang bisa dipertanggung-jawabkan secara positif-ilmiah. Dan kata orang, keadaan ini telah mengimplikasi beberapa hal, antara lain:

1. Dengan ajaran ini orang harus menempatkan diri sebagai seorang pengamat objektif, dari luar tatanan hukum perspektif eksternal;

2. Berdasar perspektif sedemikian, orang harus membatasi tatanantatanan tertentu dari sistem konseptual aturan hukum.

Terutama gejala-gejala (masalah-masalah) yang berkenaan dengan hukum yang mungkin ada atau hukum idiil atau berkenaan dengan perasaan keadilan dari hukum, yang dalam Filsafat Hukum sering menempati posisi sentral untuk dipersoalkan, berada di luar lingkup ajaran ini. Ajaran ini hanya bersinggungan dengan hal memaparkan berbagai tatanan hukum yang ada dan dari dalamnya memunculkan "aspek-apsek umum" yang dapat berlaku untuk tiap tatanan hukum Konkretnya, dengan ditampilkannya perkataan "umum" (algemeene allgemeine, general, generale) dalam istilah Ajaran Hukum Umum di situ, dikarenakan pada gilirannya ajaran itu bermaksud mengobjeksikan (menempatkan) struktur elementer dari asas-asas serta konsepsi-konsepsi fundamental yang berlaku "umum", yang diasumsikan pasti ditemukan orang di tiap-tiap level sistem konseptual aturan hukum positif di seluruh dunia, sebagai perhatian utama dalam misi-misi positifnya.

Ajaran ini tidak dimaksudkan sebagai upaya spekulatif-reflektif sebagaimana digiatkan para filsuf, melainkan suatu usaha ilmiah positif untuk menggali sisi-sisi karakteristikal dari hukum, serta sisi-sisi hakiki dari hukum. Ajaran Hukum Umum ini diasumsikan sebagai disiplin yang bebasnilai, oleh karenanya metodenya akan bersandar pada perspektif ilmiah positif, sehingga resultat yang nanti diejakulasikanpun sama sekali terketanggungjawabkan secara objektif ilmiah. Dengan kata lain ruang-ruang pengembanannya harus dibebaskan dari rantai-rantai evaluativitas (tiap-tiap 
usaha menilai-nilai putusan nilai) yang mempengaruhi sudut pandang penstudinya, dengan kata lain ia bebas dari titik tolak normative penstudi terkait, alias tidak normative sama sekali. Dalam kualitas sedemikian, ajaran ini tearah untuk menganalisis gejala-gejala hukum dengan cara yang secara metodikal dapat dipertanggung-jawabkan. Dan dengan demikian dapat sampai pada inferensiasi-inferensiasi yang secara faktual dapat diveridikasi dan didukung dengan tradisi-tradisi ilmiah. Baik dari sudut kebermetodean maupun pada resultat yang di ejakulasi.

Semisal prinsip pacta sunt servanda (utang dibayar utang). Selain mempelajari asas-asas yang berlaku umum itu, ia juga berusaha menarik generalisasi atas konsep-konsep kepemilikan (hak milik), menawarkan klasifikasi tentang hukum privat dan hukum publik yang dipandang sama (berlaku umum) pada semua tatanan hukum yang niscaya merupakan bagian dari setiap sistem konseptual aturan ukum positif. Nampak bahwa Ajaran Hukum Umum ini, sangat memperhatikan ciri yang berlaku umum dan aturan-aturan umum dan sistem-sistem hukum, atau ia terarah pada upaya mengali apa yang berlaku secara general pada tiap-tiap sistem konseptual aturan hukum positif, bukan keharusan-keharusan normatif (kaidah-kaidah perilaku) yang mau dikonfrantasi kepada situasi-situasi problematik. Dengan begitu, ciri utama dari ajaran ini, bila kita mengomperasinya dengan Teori Hukum yang hari ini kita kenal, adalah terutama soal "problematisasi" yang padanya masih relatif terbatas dan kerapnya ia bersandar pada fase kemurniaan ontologikal. Dalam kerangka ini orang berupaya mencari asasasas dan konsep-konsep (pengertian-pengertian) yang dapat ditetapkan sebagai bersifat hakiki bagi hukum. Dari keseluruhan eksponen ajaran ini, yang termasyur adalah Adolf Reinach (1883-1917), yang sebagaimana di atas dipaparkan bahwa dalam kesibukannya ia berupaya mengkonstruksi sebuah bangunan ontologikal dari hukum yang bersifat platonik. Bagi Reinach terdapat unsur-unsur yuridikal apriori yang ideal, yang memiliki actual di bidang hukum. Dengan itu, keseluruhan temuannya itu, bukan apa yang anda maksudkan sebagai kaidah-kaidah yang terikat pada ruang-ruang pengolahan praktikal keberadaan yang mandiri, terlepas dari fakta apakah unsure-unsur tersebut menemukan atau tidak menemukan endapannya (perumusannya) dalam suatu tatanan hukum positif. Konsep-konsep yuridik dalam pandangannya tidak diciptakan tapi justru "ditemukan" oleh para yuridis. $^{3}$

3 Sebagaimana bangunan ontologikal yang anda temui pada bidang lainnya, bangunan ontologikaln dari hukumn inipun, dikonstruksi lewat cara-cara spekulatif dan intuitif (fase-fase perenungan), ini adalah ihwal yang menjadi gaya khas tersendiri daripada ontology ini. Lapangan penelitian di bidang ontology ini sendiri, sering disebut-sebut sebagai medan 
Kami kira dengan ciri semacam itu, ia memaksakan diri untuk berupaya menganalisis secara ilmiah positif tipikal problem-problem yang jelas-jelas ada dalam derajat instuitif (metafisik), semisal:

1. Unsur-unsur hakiki apa yang dapat diselusuri orang dalam tiap sistem konseptual aturan hukum positif?

2. Kecenderungan apa yang menyatakan bahwa unsur-unsur ini meniscayakan perwujudan tiap sistem hukum?

Dari dua poin ini jelas bahwa, dengan anda akan berupaya menjelajahi dan mencari ruangan yang di dalamnya sisi-sisi ontologikal dari tiap-tiap hukum positif itu bersembunyi, anda akan menguraikan apa itu hakikat dari hukum, dengan cara melampaui rute-rute yang sama sekali ilmiah positif. Sehingga anda berbuat sesuatu yang lain pada jawaban itu, bahwa anda akan memberikan suatu landasan yang ilmiah-positif, pada sesuatu yang bersifat filosofikal murni.

Di sinilah justru letak kegagalan dari apa yang digagas orang dengan ajaran ini, bahwa anda berupaya mencari sesuatu yang hakiki dengan mengutamakan tradisi-tradisi bermetode yang murni positif (bebas nilai). Sementara anda tidak bisa menampik bahwa struktur-struktur dasar, atau apa yang menjadi asas-asas dan hukum itu sendiri hanya akan mungkin dipahami dalam derajat normtif, tentu mustahil bagi anda selaku penstudinya untuk bisa bebas dari nilai, sedang apa tengah diolahnya sendiri justru besaranbesaran evaluative belaka. Dengan pengutamaan semacam itu, ajaran ini hanya akan sampai pada zona kontradiksi internal. Bahwa apa yang

penelitian yang tertua dalam disiplin Filsafat. Bahkan pemikiran rasional gaya baratpun, sesungguhnya diawali dari munculnya aktus-aktus perenungan di bidang ontology ini. Thales misalnya, seorang filsuf Yunani yang hidup setidaknya antara 625-545 B.C, selaku orang yang dianggap sebagai orang pertama yang mengupayakan ontology ini, telah mempercontohkan secara gemilang pada kita sebagaimana ia berspekulasi dan berefleksi (merenung-renung) tentang air, yang mengantarnya untuk sampai pada inferensiasi bahwa air adalah substansi terdalam dari segala sesuatu, dengan kata lain air adalah asal muasal dari segala yang ada. Lewat resultat dari perenungannya itu sesungguhnya Thales hendak mengatakan bahwa segala sesuatu berasal harus bermula sebuah ihwal-ihwal yang substansial. Filsafat, selaku yang menjadi stasiun dari medan penelitian ontology ini selalu bersinggungan dengan bahasa, dan bahasa yang digunakan para filsuf dapat dipandang sebagai model bahasa yang mengemban misi sebagai alat yang mempermasalahkan segala realitas yang diperhadapkan pada penstudinya itu. Sejalan dengan pendapat ini, maka usaha pertama untuk dapat memahami ontology ini adalah dengan jalan menempatkan dalam sebuah tatanan sebuah daftar yang didalamnya dijejerkan terminologi-terminologi elementer untuk operasionalisasi dari ontology ini antara lain: being (yang ada), reality (realitas), existence (eksistensi), change (perubahan), one (tunggal), dan many (jamak). Dan sesungguhnya, berbagai aliran di bidang ontologi ini didirikan sekitar sikap yang menyetujui maupun yang menolak sejumlah pernyataan-pernyataan tertentu yang menyangkut penggunaan-penggunaan terminologiterminologi elementer di atas. 
dipandang sebagai empiric dalam kenyataannya justru menjadi sesuatu yang metafisikal murni. Bukanlah seyoginya anda bertolak dari hal yang "a priori" ketika menginginkan suatu cirri yang universal dalam apa yang anda objeksikan. Sungguh sisi universalisasi ini yang diburu ajaran ini, membuat kami kembali terkenang pada yang dilantunkan Aquinas dengan gagasannya yang klasik itu, yakni (ajaran) hukum kodrat, yang padanya bila kita menarik sebuah kompa rasi, tentu satu-satunya diferensiasi antara Ajaran Hukum Umum ini dengan besaran yang dipromulgasi dalam ajaran hukum kodrat yang klasik itu adalah bahwa dengan Ajaran Hukum Umum orang mencari ciri-ciri ini (universalitas) di dalam kenyataan ketimbang di dunia rasio (in de rede), yang terjadi dalam ajaran hukum kodrat justru tidak demikian yang mengutamakan universalisasi itu di tataran keharusan. Aquinas secara gemilang mengonfigurasi gagasannya itu, dan sangat mempengaruhi pemikiran orang mengenai hukum di kemudian hari, sedang Ajaran Hukum Umum ini terpaksa harus berpuas diri dengan situasi-situasi kegagalan yang membuntutinya, ia harus pasrah menerima sebuah kartu merah dari gelanggang karya-karya tulis ilmiah dan bangku-bangku kuliah di kemudian harinya.

Karena kegagalan itupun, dikisahkan bahwa Ajaran Hukum Umum ini belakangan hari banyak ditinggalkan para penulis dan bangku-bangku kuliah di Jerman sendiri maupun di luar Jerman, sehingga dalam perkembangan selanjutnya, ia seolah lenyap diterbangkan angin perubahan. Bahkan di Indonesia sendiri, hingga hari ini kita nyaris tidak mendengar namanya disebut-sebut oleh penulis-penulis hukum maupun para guru besar-guru besar dan komunitas pengajar di ruang-ruang kuliah di tanah air. Sampai suatu ketika muncullah Teori Hukum di Rusia, sebagaimana telah sedikit disinggung di atas.

Lepas dari hal itu, hingga hari ini, kontradiksi dalam ihwal kedekatan relasional antara pokok-pokok telaah dari Ajaran Hukum Umum ini dengan yang dimunculkan dalam Teori Hukum masih terus bergulir. Sebagian bersikukuh dengan pendirian bahwa Teori Hukum tak lain sudah berevolusi ke dalam sebuah nama baru, namun sebagian penulis-penulis lain, semisal Paul Scholten justru menekankan bahwa tidak ada sama sekali tendensi kedekatan relasional antara keduanya itu (tidak bisa dicari-cari benang merahnya). Bahwa Teori Hukum dengan fasilitas kritikan dan analisa yang ditawarkannya selalu bertolak dari hal-hal yang tampak, dengan kata lain kritik dan analisasinya itu diarahkan pada bagian-bagian formal dari hukum, sedang Ajaran Hukum Umum sembari berjalan ia berupaya mencari apa yang informal berlaku bagi hukum (unsur-unsur hakiki), dengan rute-rute yang biasa dilalui oleh disiplin-disiplin ilmiah-positif, itu bedanya. 


\section{Bagan I, Ajaran Hukum dan Kesibukan Penelitiannya}

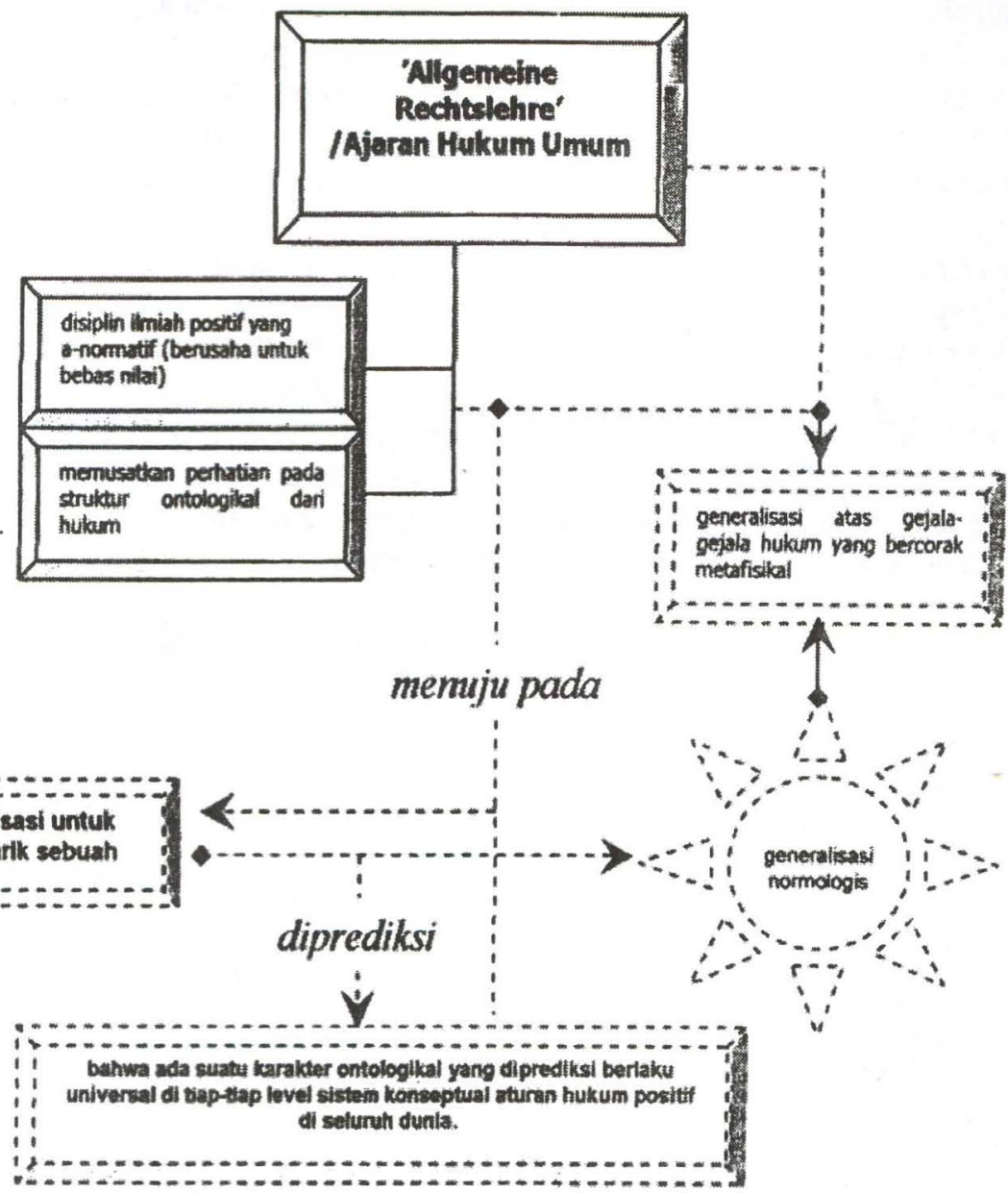

\section{HERMAN BAKIR 2005}

Apapun prasangka-prasangka yang ditampilkan Scholten maupun mereka yang menyatakan diri kontra dengannya, kita harus mengakui bahwa apa yang dikerjakan pengusung Ajaran Hukum Umum tidak berbuah kesiasiaan. Ia setidaknya, telah memunculkan suatu titik cerah bagi gagasan awal lahirnya sebuah disiplin ilmiah-positif a-normatif yang eksis sama menyebutnya dengan Teori di antara Filsafat Hukum dan Ilmu Hukum, yang kita telah bersama-sama menyebutnya dengan Teori Hukum. 


\section{Kegilaan Ilmiah Pertama yang Sukses di Bidang Hukum (Emergenitas Teori Hukum Klasik)}

Dengan pemahamannya yang teoretikal itu, Kelsen berupaya untuk secara tajam merekayasa regionasi pendikotomian metodologi (pemisahan kebermetodean) untuk kajian-kajian ilmiah atas hukum. Di sini ia mengkonforntasikan dua tradisi ilmiah, yakni: tradisi-tradisi berpikir dan bermetode dari ilmu-ilmu alam yang ilmiah-positif, yang pola pengoperasiannya sendiri merujuk pada "asas kausalitas" (relasi kausal, proximate cause), dengan metode yang dikonsumsi dalam disiplin-disiplin normatif yang di rute-rute penelitiannya justru mempekerjakan "prinsip volisional". Dengan itu, Kelsen mencoba melancarkan serangan (kritik) yang sangat menukik pada apa yang telah dikerjaka eksponen-eksponen Allgemeine Rechtslehre dan pendukung-pendukungnya di atas, yang dengan serangkaian uji coba terdahulu, mereka ini begitu mengagung-agungkan elaborasi segi keilmiahan dari hukum lewat pengaplikasian tradisi-tradisi berpikir dan bermetode yang dikembangkan dalam ilmu-ilmu alam yang secara berketeguhan menyandarkan diri pada asas kausalitas dan deterministik. Konkretnya, Teori Hukum yang di identifikasinya sebagai Rechtswissenschaft (Rechtsdogmatiek, di kita Ilmu Hukum) bertugas memurnikan hukum dari intervensi tiap-tiap elemen dari ilmu-ilmu alam yang sedemikian. Tidak hanya itu, Teori Hukum yang menurutnya adalah satu-satunya forum pengembanan ilmiah di bidang hukum, tidak melulu bermain di tataran sistematisasi dan inventarisasi aturan hukum, tapi juga akan bermain di level aplikatif dari hukum (ruang pengolahan praktikal). Sementara itu, untuk rute-rute penelitian Teori Hukum sendiri, umumnya Kelsen menunjuk pada jalur dimana komunitas teoretisi bidang ini hendak secara sungguh-sungguh memulai perjalanannya untuk melakukan pencarian di manakah karakteristik yang berlaku umum di tiap-tiap tatanan hukum positif di seluruh dunia itu mengendapkan diri, karena itu ia menyebut teorinya itu sebagai general theory. Dan apa yang seharusnya dihasilkan komunitas ini di level itu menurut Kelsen adalah bahwa hukum (tatanan hukum) itu secara umum berkarakter "valid" (mengikat). Ihwal kemengikatan dari tatanan hukum ini dilandaskan pada tatanan hukum positif lain yang setingkat ada di atasnya, begitulah situasi ini akan berlangsung secara runut hingga validitas (kemengikatan) itu berakhir pada suatu "kaidah moral" yang disebutnya sebagai grundnorm, kaidah yang mendasari keseluruhan tatanan hukum positif yang dianut. Dan bunyi dari perkataan grundnorm itu sendiri menurut salah satu sumber adalah:"orang seyogianya mematuhi apa yang diperintahkan konstitusi". 


\section{A. Pengantar}

Diriwayatkan, usia berkecamuknya perang dunia pertama, secepatnya tersiar kabar beberapa penjuru dunia tentang telah bermunculannya pemikir-pemikir dari generasi baru di tanah Eropa Daratan, khususnya di Vienna (Wina), Austria. Perkataan "baru" di situ dimaksudkan, bahwa mereka ke permukaan tampil untuk menawarkan sesuatu yang sama sekali berbeda dari yang sampai sejauh itu diupayakan ilmu-ilmu tertentu yang kebetulan bergiat mencari pemecahan bagi problema-problema aktual berkenaan dengan hukum di masyarakat, termasuk Ajaran Hukum Umum sebagaimana yang kita sudah singgung di atas. Konkretnya, para pemikir ini hadir untuk mempertontonkan tradisi-tradisi berpikir dan bermetode baru, tapi juga disorotkan pada penyelesaian problem-problem tertentu yang sebelumnya terbengkalaikan (tidak terselesaikan) oleh sebab ketidak berdayaan tradisi-tradisi Filsafat yang terlalu ontologikal serta Ilmu Hukum yang terlalu teknikal itu (atau kalaupun terjawab, ia sama sekali tidak memuaskan). Ketika itu tradisi-tradisi bermetode dan berpikir Filsafat (Hukum) maupun medan-medan penelitian dari Ajaran Hukum Umum sepertinya telah membuat generasi pemikirpemikir baru itu cukup mengatupkan geraham mereka, sebab greget tiga ilmu di atas tidak terasa sama sekali untuk masalah-masalah actual. Ihwal inilah yang pada gilirannya membuat orang-orang ini memutuskan untuk segera beralih pada sesuatu yang lebih "teknikal" atau sama sekali "membumi" (pragmatis, aktual), tapi lebih teoretikal ketimbang Ilmu Hukum sendiri. Lalu dipikirkanlah sebuah ilmu yang direkayasa agar solusi-solusi yang ditawarkannya nanti dapat menetralisasi kekeruhan-kekeruhan yang sementara itu mewarnai problema-problema di tataran aktual untuk bidang hukum. Tradisitradisi berpikir yang diketengahkan para ilmuwan muda itu, diusahakan untuk terikat pada praktek, sekaligus ia membuka diri bagi verifikasi-verifikasi ilmiah-positifm baik dalam bentuk justifikasijustifikasi maupun falsifikasi-falsifikasi tertentu.

Demikianlah, fragmentasi postur situasi yang terjadi di Vienna Austria beberapa tahun setelah usai berkecamuknya perang dunia pertama, orang-orang ini (komunitas pemikir di atas) ketika itu sadar betul bahwa solusi-solusi Filsafat tidak mungkin bila dikonfrantasi pada situasi-situasi problematik dalam derajat aktual, khususnya yang berkenaan dengan hukum di masyarakat, sebab yang ditawarkan itu terlalu di "awang-awang", sedang Ilmu Hukum sendiri terlalu ternikal, dari kadar teknikalitas yang kental ini justru kerap menggiring orang 
untuk melahirkan kekeringan bahkan kematian dari sebuah Sistem Hukum. Dengan dukungan Filsafat Hukum, Ilmu Hukum memang tahu apa yang harus dicarinya (nilai-nilai dari negeri kesadaran), tapi ia benar-benar dalam keadaan bingung sebab tidak menemukan jalan bagaimana ia harus sampai pada apa yang dicarinya itu (jalan untuk menuju pengetahuan). Bila diibaratkan itu adalah sebuah "jalan", tentu jalan itulah yang ingin dibangun komunitas pemikir-pemikir muda itu.

Dari sekian banyak pemikir-pemikir muda yang tampil ketika itu, salah satunya yang cukup akrab di telinga orang kita (orang hukum) hingga hari ini tentunya adalah Hans Kelsen (1881-1873), pria yang di beberapa kesibukan intelektualnya itu, secara sangat gemilang telah memproses (mengolah) teknik-teknik berpikir dan bermetode ilmiahpositif itu untuk pada gilirannya diperterapkan di bidang hukum. Kategori-kategori teknikal itu yang pada gilirannya ke permukaan tampil menjadi gagasan awal tentang Teori Hukum, sebagian orang lebih senang menyebutnya dengan Reine Rechtslehre (The Pure Theory Of Law: Teori Hukum Murni). Sesungguhnya, dengan yang digagasnya itu, Kelsen berusaha menawarkan sebuah jalan yang lain kepada Ilmu Hukum, bagaimana ilmu ini harus benar-benar dipisahkan dari nilai-nilai intuitif yang justru mau dicarinya di rute-rute yang biasa dilaluinya.

Dari hari pertama kemunculan kolektivitas tulisan-tulisannya yang mencengangkan itu, Kelsen dapat dikatakan telah mencari posisi sebagai seorang "patron" dalam sejarah perspektif ajaran tentang hukum. Bahkan hingga hari inipun andan bisa mengatakan bahwa ia begitu disegani dan begutu dalam menginspirasi tulisan-tulisan para penstudi kelas dunia papan atas. Dengan ide-ide yang dieksposisi olehnya itu, ia telah membawa perubahan yang signifikan berkelakuan orang atas dunia pembelanya saran saya, ada baiknya anda lebih dulu mengenali ide-ide besar yang telah ditulisnya, sebelum anda lebih jauh berenang ke tengah-tengah kancah pergaulan yang didalamnya orang memahami hukum sebagai sisi intelektual kehidupan masyarakat manusia.

Kelsen tidak hanya disegani di kalangan yuris-yuris yang hidup di masanya, tapi juga setelahnya. Buktinya, lihat saja bagaimana seorang filsuf hukum Amerika Serikat kenamaan yang juga hidup di masanya (segenerasi), Roscoe Pound, di tahun 1934 menuliskan dengan sangat indahnya:....Hans Kelsen was unquestionably the leading jurist of the time. $^{4}$ (...tak lagi diragukan bahwa bahwa Hans Kelsen adalah orang 
yang telah mengarahkan ahli hukum dalam perputaran sang waktu). Sementara itu, H.L.A Hart menuliskan Kelsen sebagai "the stimulating writer on analytical jurisprudence of our day.". (penulis yang menstimulasi munculnya rute analytical jurisprudence" di jaman kita). Dan seorang filsuf dan logika dari Finlandia, Georg Henrik von Wright coba membanding-bandingkan Kelsen dengan Max Weber (seorang pakar kenamaan yang datang dari komunitas ilmu sosial), bahwa hanya akan nada dua pikir, katanya, ... yang telah begitu dalam memberikan pengaruh, bagaimana ilmu-ilmu sosial telah sampai pada perkembangannya yang terakhir di abad ini (abad 20), mereka tak lain: Hans Kelsen dan Max Weber. Oleh banyak orang, Kelsen kerap disebut-sebut sebagai salah seorang eksponen dari Positivisme Hukum, entah benar entah tidak yang dimaksudkan ini. Namun setidaknya ciri itu memang tampak padanya, suatu ketika ia ingin berdiri pada garis yang sejajar dengan pendahulunya. Artinya, atas hal yang diidentifikasi dengan sebutan hukum itu Kelsen tidak hendak menyama-nyamakannya dengan bagian natural reality, atau apa yang kita sebut asas-asas hukum alam yang berlaku umum itu. Kelsen sering menganggap hukum sebagai sesuatu yang secara ekslusif hadir sebagai agregasi kaidah-kaidah yang antara satu dan lainnya berkonspirasi dalam kerangka sistemik dan konseptual yang secara riil mau "diundangkan" lewat proses validitasi dari rute-rute politik, yang sama sekali harus dipisahkan dari unsur-unsur diluarnya, termasuk hukum alam itu sendiri. Dan untuk perkataan hukum ia memberikan sebuah definisi, yakni: jalinan kaidah-kaidah yang otoritatif atau system of norms yang padanya terberi sebuah otoritas. Dan hukum hanya akan benar-benar dalam taraf dimengerti sebagai hukum yang benar-benar hukum, ketika ia sebelumnya telah dipisahkan dari hukum alam, lalu pada gilirannya dieksposisi sebagai jalinan system of norms (sistem dari kaidah-kaidah) yang tervaliditasi.

Inilah semangat yang sedemikian tertanam yang anda bisa lihat pada diri seorang Hans Kelsen, sebuah modal pemikiran yang sepertinya mirip Positivisme Hukum. Pendirian ini sangat mewarnai serta memberikan karakter khas tersendiri pada berbagai dalil yang telah diketengahkan di sepanjang perjala nan hidupnya. Ideology ini selalu dia pegang teguh hingga tulisan terakhir beberapa saat sebelum

${ }^{4}$ Stanley L. Paulson, "Introduction: Hans Kelsen, Introduction to the Problems of Legal Theory", transtlation: Bonnie Litschewski Paulson \& Stanley L. Paulson (Oxford: Clarendon Press Oxford, 1996), hal. xvii.

${ }^{5}$ Ibid., hal. xviii. 
ia menemui hari kematiannya, walaupun menurut banyak orang dari beberapa postulat yang dipublikasi olehnya, ia justru seperti menyimpang dari keteguhan ini (suatu ketika dalam beberapa kiprah keilmuannya, terimplisitkan bahwa ia bukan seperti seorang eksponen Positivisme Hukum).

Lepas dari hal pro-kontra di atas (apakah Kelsen itu termasuk kedalam barisan komunitas pengusung Positivisme Hukum atau tidak), satu hal lain yang tak lagi kita tidak dapat untuk tidak menyatakan pro (dapat dipungkiri) tentunya, hanya beliau inilah satu-satunya orang yang akan layak memperoleh sebutan sebagai "bapaknya Teori Hukum dunia", sebab dari kebrilyanan otak nyalah tergulirkan sudah berbagai ide penting berkenaan dengan landasan berpikir dan bermetode untuk tiap-tiap kesibukan pengkajian secara ilmiah berkenaan dengan ihwal tatanan hukum positif, yang kita sebut dengan Teori Hukum itu. Dia telah sekaligus menjadi peletak dasar dari Teori Hukum sebagai suatu disiplin yang mandiri (autono mous discipline), selain tampil selaku eksponen pertama yang mempublikasi perkataan Teori Hukum, demikian diterjemahkan Arief dari penuturan Gijssels dan van Hoecke. Atas kepertamaan ini, Gijssles dan van Hoecke pada gilirannya menunjuk misalnya ke gagasan-gagasan brilyan yang ditulis Kelsen di jurnal Revue internationale de la theorie du droit-Internationale Zeitschrift fuer Theorie des Rechts, yang turut diterbitkan sendiri oleh Kelsen pada 1926 lalu. Selain Kelsen, di jurnal itu juga tampil sejumlah nama lain yang turut meramaikan, yakni: Leon Duguit dan Francois Weyr. Yang menarik bahwa untuk jurnal ini, Kelsen, Duguit maupun Weyr tidak menyebut perkataan yang lazim disebut orang ketika itu yakni: Allgemeine Rechtslehre (theorie generale du droit), mereka justru menyebut jurnal itu dengan perkataan baru, jurnal Teori Hukum. Gijssels dan van Hoecke, lebih jauh menyebutkan bahwa penjelasan mengenai pilihan perkataan itu dapat ditelusuri pada kata pendahuluan pada nomor pertama jurnal ini. Mengapa jurnal itu menyandang nama Teori Hukum dan bukan Filsafat Hukum, bahwa pada jurnal ini pembahasan dibatasi pada suatu analisis ilmiah-positif terhadap hukum, dengan kata lain orang memandang Teori Hukum Kelsen ini sebagai teori tentang hukum positif. Sedang Filsafat Hukum akan membuat orang menahan diri pada diskusi-diskusi spekulatif berkenaan dengan ihwal keadilan, kelayakan (equity), hukum kodrat atau hukum absolut.

Dalam Teori Hukum Kelsen ini tidak diusahakan studi yang disorotkan pada penjelajahan mengenai struktur-struktur atau ciri-ciri funda mental yang berlaku universal pada tiap-tiap aturan hukum serta 
berbagai konsep-konsep hukum yang diprediksi berlaku umum di keseluruhan tatanan konseptual aturan hukum positif, melainkan tentang pengkajian "problema-problema yang sama" pada berbagai sistem konseptual aturan hukum. Masalah-masalah ini melingkupi ihwal:
a. Karakteristik (sifat dari hukum);
b. Hubungan antara hukum dan Negara;
c. Hubungan antara hukum dan masyarakat;
d. Pengertian-pengertian dasar dari hukum;
e. Metode-metode untuk memperoleh pengetahuan hukum;
f. Hubungan timbale balik antara berbagai sistem hukum (tatanan hukum positif, nasional dan internasional;
g. Serta masalah-masalah lain yang sejenis.

Keseluruhan persoalan-persoalan ini dipandang sebagai persoalan elementer yang mutlak diperlukan untuk diolah di tiap kajian ilmiah berkenaan dengan tatanan hukum positif konkret. Dalam Reine Rechtslehre, edisi pertama yang diterbitkan di tahun 1934, sebuah usaha translasi dari Bonnie Litschewski Paulson \& Stanley L. Paulson kedalam bahasa Inggris, berjudul Introduction to The Problems of Legal Theory. Kelsen mempersoalkan beberapa problem berkenaan proporsi teoretikal dari hukum, beberapa di antaranya yang menurut kami teoretik adalah:

a. Dualisme antara hak hukum objektif dan subjektif;

b. Konsep hak subjektif;

c. Konsep subjek hukum;

d. Konsep hubungan hukum;

e. Konsep kepatuhan hukum;

f. Kaidah hukum sebagai obligasi hukum;

g. Kaidah hukum sebagai hak hukum;

h. Analisis konsep mengenai orang;

i. Karakteristik universal dari The Pure Theory Of Law;

j. Sistem hukum dan struktur hirarkhialnya;

k. Sistem hukum sebagai sistem dari kaidah-kaidah;

1. Masalah interpretasi;

m. Metode pembentukan hukum;

n. Negara sebagai sistem hukum;

o. Signifikansi ideological dari dualisme hukum privat dan hukum publik;

p. Negara dan hukum internasional;

q. Unitas hukum internasional dan hukum Negara; 


\section{r. Dan seterusnya.}

Dari persoalan-persoalan yang ditampilkan di atas, Nampak bahwa selaku seorang "teoritisi" (di bidang hukum), Kelsen telah secara konsisten berjerih payah memfluktuasikan (menurun-naikkan) nilai-nilai untuk dapat menemukan sebuah pemahaman yang lebih rasional lagi (membumi), terutama ketika hukum harus dipandang sebagai suatu produk dari kegiatan intelektual manusia. Pada saat aksi semacam itu digelar, sesungguhnya Kelsen tengah berusaha menarik analogi-analogi tertentu (kegiatan membanding-bandingkan satu benda dengan benda lainnya) dengan mengonsumsi pendekatan-pendekatan formal, sebagaimana diatas telah sedikit diuraikan. Di situ Sistem Hukum seolah adalah sistem dari benda-benda (yang selalu mempunyai atribut material, atribut formal), bahwa sistem hukum mempunyai unsur-unsur yang tersusun dalam suatu skema tertentu. Dari bentuk luarnya itu, Kelsen telah sukses melakukan proses analogi pada beberapa tatanan hukum positif. Sehingga sampailah ia pada suatu inferensiasi menyeluruh, bahwa dari bentuk luarnya hukum menjelaskan suatu atribut yang universal, yakni : "tatanan hukum" (sistem konseptual aturan hukum)".

Bagi J.W. Harris misalnya, gagasan ini dipandang sebagai dalil yang disandarkan pada buah pemikiran dari pendahulunya yang juyga sangat masyhur, yakni: Immanuel Kant (1724-1804). Kant sendiri telah mengembangkan gagasan tentang epistemologinya (teori ilmu, theory of knowledge) untuk bidang ilmu alam, bahwa seseorang hanya dapat secara jernih (murni) memahami dan melukiskan gejala-gejala alam yang diperhadapkan padanya, ketika ia pada dirinya mengaplikasi kategori-kategori tertentu yang selalu diperoleh dari buah-buah pemikiran (penalaran), bukan dari keterberian-keterberian yang alami, sebagaimana halnya waktu, ruang, ataupun sebab musabab. Kedalam proses pemahaman itu, sekelompok gejala-gejala alam akan dirangkum oleh subjek dalam suatu wadah yang meletakkan masing-masing gejala itu pada jalur-jalur yang berkaitan menurut penalaran yang serasi dari aturan sebab-akibat yang akan disebut sebagai "hukum alam".

Dari titik menghadap yang searah dengan itu, Kelsen pun mengargumenkan bahwa seharusnya penstudi hukum ketika menjalankan Ilmu Hukum, dalam usaha menggambarkan hukum, selalu beranjak dari presuposisi-presuposisi bahwa "sistem kaidahkaidah yang kedalamnya ada validitas itu, tidak terjadi konflik antara kaidah yang satu dengan lainnya". Artinya, hukum (massa material yuridik) yang tadinya sebagai sebuah komunitas yang tidak beraturan, 
kemudian oleh Ilmu Hukum dirangkum dalam suatu wadah, untuk diserasikan secara sistemikal, berdasarkan aturan asas sebab-akibat, sehingga tidak terjadi konflik antara kaidah yang satu dengan lainnya.

Untuk itu, Ilmu Hukum harus kapabel dalam menggiring mereka (komunitas kaidah-kaidah itu) agar dapat memaparkan diri dalam suatu struktur (skema) hierarkhis (yang oleh Kelsen disebut sebagai hierar chy of norms). Suatu struktur yang terjalin dari konspirasi kaidah yang lebih abstrak ke kaidah yang lebih konkret begitulah seterusnya. Dan pendeskripsian semacam itu hanya mungkin bila kita mengasumsikan sebuah grundnorm atas keseluruhan kaidah-kaidah dalam sistem dimana mereka telah memperoleh validitas. Kaidah yang satu memperoleh validitas dari kaidah yang diatasnya, begitulah seterusnya hingga berakhir dengan suatu kaidah tertinggi yang kita sebut sebagai grundnorm itu.

Yang lebih gila lagi, selain itu Kelsen juga memunculkan dan mengembangkan sebuah gagasan yang dibingkai dalam proporsi ilmiah dengan sedemikian mentakjubkannya. Itulah sesuatu yang telah disebutnya sebagai The Pure Theory of Law (Reine Rechtslehre). Kami meyakini gagasan The Pure Theory of Law ini adalah, gagasan mengenai teori di bidang hukum pertama kali yang pernah muncul ke permukaan. Meskipun telah banyak kejadian-kejadian besar, yang memunculkan trauma pada diri orang-orang untuk tidak lagi melirik Teori Hukum lagi, namun setidaknya harus diakui bahwa hingga hari ini, The Pure Theory of Law masih yang terbesar (terjenius) dari keseluruhan yang pernah termunculkan kepermukaan.

\section{B. Spirit Pemurnian Ini, Mendikotomi Dataran Ide dari Realitas}

Dalam kebrilyanannya itu, Kelsen mengusahakan secara teoretik konfigurasi dikotomi antara "ada" (das Sein) dan "keharusan" (das Sein), dan situasi ini dengan sendirinya berimplikasi pada keterpisahan, ketidak bersambungan antara dua dunia, yakni: dunia alamiah dan dimensi validitasi. Kelakuan ini, bagaimanapun, mengundang ketidak puasan dari banyak pihak, bahkan dipandang sebagai sebuah kegilaan (penyimpangan kognisi). Menyusul itu, mengalirlah berbagai kritik yang cukup meruncing sebagai reaksi atas itu semua. Kebanyakan dari orang-orang ini mempersoalkan dua hal, pertama, bukanlah ketika sistem kaidah-kaidah itu menginterpretasi (dan memberikan penilaian) unit-unit realitas (sosial) dengan menyatakan bunyi (dari interpretasi itu) sekualitas dengan yang diharuskan (sistem normatif) itu, tentu pada dua sistem harus 
diupayakan keselarasan-keselarasan (commons) antara satu dengan lainnya. Kedua, bukankah hanya asosiasi sintetikal antara realitas dan validitas saja, yang akan sungguh-sungguh membuka kemungkinan bagi sistem normatif itu memperoleh rujukan-rujukan yang berarti: sebuah realitas sosial untuk kategori varliditas. Setajam apapun kritikkritik ini dilancarkan, Kelsen tentu punyai argumen-argumen yang kuat, yang akan menolongnya menangkis hujaman-hujaman itu. Suatu ketika Kelsenpun menyerukan:

The Pure Theory of Law is a theory of positive law, of positive law as such, and not of any special system of law. It is general legal theory, not an interpretation of particular national of international legal norms.

Yang setidaknya artinya:

The Pure Theory Of Law tak lain dari sekedar teori mengenai hukum positif, dari ihwal hukum positif sedemikian itu, ia tidak melibatkan diri pada perbincangan berkenaan ihwal sistem khusus dari hukum. Teori ini adalah sebuah teori general, bukan sebuah interpretasian atas kaidah-kaidah hukum tertentu baik di level nasional maupun internasional sekalipun.

Demikianlah, di dalam tradisi berpikir dan bermetode yang kerap disebut-sebut Kelsen sebagai "analisa positivis" (positivist analysis), yang disini bisa berarti "analisanya kaum positivis", hukum ditelaahn (dianilisis) secara logis dan dalam kerangka orientasi yang ilmiahpositif. Dengan begitu, tentu pada pekerjaan ini akan tercium bau-bau empirikal (ilmiah). Dan ketika ada bau-bau yang sedemikian, tentu yang diperhatikan itu, berkisar pada sudut-sudutnya yang Nampak atau melulu bagian-bagiannya yang formal. Dan pada hukum, menurut Kelsen dimungkinkan bagian-bagian tertentu yang beratribut formal semacam itu. Bahkan daya jelajah dari analisis ini sendiri hanya akan pada level ilmiah-positif ketika orang benar-benar menelusuri hukum dari sisi formalnya (permukaannya) itu. Bagian yang formal itu hanya akan mungkin ketika hukum itu dilihat sebagai unit-unit "tatanman hukum positif" yang pada masing-masingnya terjalin relasi konspiratif secara hirarkhial di bawah bangunan "grundnorm". Sisi formal dari hukum itu sebagaimana dibicarakan di bagian sebelumnya itu melingkupi pertanyaan tentang what the law is?, sedang sisi informal, pertanyaannya berkisar pada what it ought to be? 
Simak saja bagaimana Kelsen mengungkapkannya: ${ }^{6}$

As theory, the Pure Theory of Law aims solely at cognition of its subject-matter, its object. It attempts to answer the questions of what the law is and how the law made, not the questions of what the law ought to be made. The Pure Theory of Law is legal science, not legal policy.

Itu bisa berarti:

Sebagai sebuah teori, The Pure Theory of Law sematamata diarahkan untuk mengognisi (mengetahui) subjectmatternya sendiri, yang menjadi objek baginya. Ia berupaya menjawab pertanyaan-pertanyaan "what the law is" dan "how the law made", bukan pertanyaan mengenai "what the law ought to be made". "The Pure Theory of Law adalah Ilmu Hukum, bukan kebijakan politik.

Atas itu, dengan berpanjang lebar Curzonpun memberikan komentarnya: Kelsen was concerned to explain what the law ini, not what it ought to be. ${ }^{7}$ Tidak hanya itu, menurut Curzon hal yang telah menjadi pokok pikiran dalam The Pure Theory of Law, itu antara lain: ${ }^{8}$

Every activity of a legal nature may be traced back to an outhoritative standard-a norm. legal norms prescribe certain types of behavior and additionally, attach sanctions to any manifestation of the contrary type of behavior. Law is considered, is term of the pure theory of as a coercive order of human behavior.

The validity of a norm is derived from it having been authorized by another legal norm of a higher rank. The legal order may be interpreted as a hierarchy made up of different levels of legal norms. The basic norm is the grundnorm the presupposed starting point of the procedure of positive law creation. Such a basic norm exists in any kind of legal order. No system of law can be established on the basis of conflicting basic norms.

${ }^{6}$ Hans Kelsen, Op. Cit., hal. 1.

${ }^{7}$ L.B. Curzon, “Jurisprudence”, ed.1, (London: Cavendish Publishing, 1993), hal. 121.

${ }^{8}$ Ibid., hal. 121. 
Setidaknya atas dalil di atas, kami telah menginterpretasi sebagai: Bahwa setiap aktivitas alamiah dari hukum anda dapat ditelusur-balik pada sebuah kaidah standar yang pada dirinya telah terinjeksi otoritas (kaidah perilaku). Kaidah hukum menggambarkan model-model tertentu dari perilaku, sekaligus melampirkan sanksi atas beberapa tiptipe perilaku yang kontrakdiktif dengan nilai-nilai yang dilesakkannya. Hukum dipertimbangkan, sebagai sebuah "tatanan kepemaksaan" yang di arahkan pada perilaku masyarakat manusia, begitulah terminologi dari The Pure Theory ini. Dalam perjalanannya, sistem itu terarah untuk memaksakan nilai-nilai perilaku yang dikandungnya sebagai pedoman perilaku bagi orang-orang. Ia memaksa tidak dengan begitu saja, melainkan disuportasi oleh validitas tertentu. Validitas yang ada padanya itu, diperolehnya lewat otoritas yang terberi pada kaidahkaidah lain yang dari sudut hierarkhis minimal setingkat lebih tinggi darinya. Dan kaidah yang diasumsikan paling elementer dari keseluruhan, yang sekaligus tampil mendasari segenap prosedur penciptaan komunitas kaidah-kaidah-kaidah hukum positif adalah "sebuah kaidah" lain, yang oleh Kelsen disebut sebagai grundnorm. Grundnorm akan juga disebut pula sebagai "kaidah fundasional" (basic norm). sebagai sebuah kaidah fundasional, "grundnorm", akan eksis dan menjadi fundasi dalam berbagai sistem konseptual aturan hukum. Kaidah elementer ini akan selalu eksis di tiap-tiap tatanan hukum positif. Tidak boleh satupun ada sistem hukum yang dapat dibentuk dengan secara substansi dan teknikal melawan nilai-nilai yang dipromosikan dalam kaidah yang satu ini (grundnorm). Dengan kata lain ihwal kemapanan hanya akan diperoleh kaidah-kaidah itu, ketika ia menghadap pada arah yang sama dengan grundnorm-nya.

\section{Penutup}

Dalam proporsi yang teoretikal, Ilmu Hukum, yang dalam hal ini adalah Teori Hukum, seyogianya mengartikulasikan hal subject matter sebagaimana diberlakukan di tiap-tiap wacana ilmiah. Bahwa sebuah teori untuk bidang hukum seyogianya beranjak untuk sesuatu yang pure (murni), dengan kata lain teori hanya akan dikonstruksi dengan membentangkan jalinan kategori-kategori konseptual, define torikal dari hal-hal yang murni sedemikian. "Negara" sebagai sebuah konsep yuridik, olehnya diartikan sebagai "penjelmaan" (hipo-statisasi, personifikasi) dari keseluruhan kaidahkaidah hukum yang valid dalam suatu territorial (yurisdiksi). Orang (individu) dalam pemahaman konsep yuridikal, adalah sebuah "entitas" yang 
membuat kaidah-kaidah hukum itu menjadi berjalan dalam eksistensinya (dilampiri dengan sanksi-sanksi). Konkretnya, tanpa adanya Negara dan orang-orang, kaidah-kaidan itu tidak mungkin memiliki teritorialitas dan menebar keangkuhan dalam eksisten sialitasnya. 


\section{Daftar Pustaka}

Agnes, Michael. Black's Law Dictionary, Ed. 6. USA: West Publishing Co, 1990.

Curzon, L.B. Jurisprudence, ed. 1. London: Cavendish Publishing, 1993.

Dardji Darmodiharjo, wawancara dengan penulis. kediaman Dardji Darmodihardjo, 7 April 2005.

Gijssels, Jan \& Mark Van Hoecke. Apakah Teori Hukum Itu?, Terjemahan B. Arief Sidharta. Bandung: Penerbitan tidak berkala No.3 Laboratorium Hukum FH Unpar, 2000.

Harris, J.W. Legal Philosophies Butterworths, London: Butterworths, 1997.

. Law and Legal Science, An Inquiry into the Concepts Legal Rule and Legal System, Oxford: Clarendon Press, 1982.

Hooft, H. Ph. Visser't. Filsafat Ilmu Hukum, Terjemahan: B. Arief Sidharta. Bandung: Penerbitan tidak berkala No.4 Laboratorium Hukum FH Unpar, 2002.

Husserl, Edmund. The Shorter Logical Investigation, Translation: J.N. Findlay. London and New York: Routledge, Taylor \& Francis Group, 2001.

Kelsen, Hans. Introduction to The Problems of Legal Theory, Translation: Bonnie Litschewski Paulson \& Stanley L. Paulson, Oxford: Clarendon Press, 1996.

Kelsen, Hans. The Pure Theory of Law, Translation: Max Knight. London \& Los Angeles: University Of California Press, 1978.

Pointier, J.A. Penemuan Hukum, Terjemahan: Arief Sidharta. Bandung: Penerbitan tidak berkala No.2 FH Unpar, 2001.

Schlick, Moritz. Positivism and Realism, dalam: The Philosophy of Science, Edited by: Richard Boyd, Philip Gasper, and J.D. Trout. London: The MIT Press, 1997.

Scholten, Paul. Struktur Ilmu Hukum, Terjemahan: B. Arief Sidharta. Bandung: Alumni, 2003.

Sidharta, B. Arief. "Disiplin Hukum: tentang hubungan antara Ilmu Hukum, Teori Hukum dan Filsafat Hukum", Jurnal Pro Justitia, Tahun XX No.3, Juli 2002. 
- Refleksi Tentang Struktur Ilmu Hukum: Sebuah Penelitian tentang Fundasi Kefilsafatan dan Sifat Keilmuan Ilmu Hukum sebagai Landasan Pengembangan Ilmu Hukum Nasional Indonesia. Ed. 2. Bandung: Mandar Madju, 2000.

Sinha, Surya Prakash. Jurisprudence, Legal Philosoph, Ed. 1. St. Paul Minn: West Publishing Company, 1993.

Unger, Roberto Mangabeira, The Critical Legal Studies Movement, United States of America: Harvard University Press, 1986.

Wacks, Raymond. SWOT Jurisprucende, Ed. 4. London: Blackstone Press Limitted, 1995.

Williams, Malcolm. Making Sense of Social Research, Ed.1. London: SAGE Publication. 2003.

Ziman, John. Reliable Knowledge: An Exploration of the Grounds for Belief in. Science, Reprinted. New York: Cambridge University Press, 1996. 